\title{
Union Wage Premiums by Gender and Race: Evidence from PSID 1980-1992
}

\author{
PHANINDRA V. WUNNAVA \\ Middlebury College, Middlebury, VT 05753 \\ NOGA O. PELED \\ Deloitte \& Touche Consulting Group, Chadds Ford, PA 19317
}

We find that the overall union wage premium is relatively stable (ranging from 22.3 to 28.4 percent), but there seems to be a convergence of union wage premiums across different demographic groups between 1980 and 1992. Nonwhite men (whose premium ranges from 23.5 to 36.2 percent) show the largest gain, followed by white women (17.1 to 30.5 percent), white men ( 19 to 26.4 percent), and nonwhite women (10 to 20 percent). One explanation for this convergence of union wage premiums might be the "equalization hypothesis" associated with unions. This converging trend could have important implications for the future of unions. If union membership can explain a portion of the gender/racial wage gap, and if women/nonwhites can obtain, through union membership significant wage premia, increased female/nonwhite union participation in highly unionized sectors that offer high union wage gains could, in time, greatly decrease the gender/racial wage differential.

\section{Background}

Evidence from past research indicates that nonwhite males gain more from union membership than their white counterparts (Ashraf, 1990; Ashenfelter, 1972; Hirsch and Addison, 1986; Farber, 1989). Nonwhite males' desire for membership is also higher (Hills, 1985; Farber, 1983) - the union-nonunion wage differential for minority men is the highest of any category of individuals (Abowd and Farber, 1982). Despite this evidence, nonwhites still face barriers to entry into unions (Ashenfelter, 1972; Gould, 1977).

Similarly women face barriers to entering unionized labor markets. Although their desire for membership may be as high as that of men and minority workers, women's participation is far weaker (Parsley, 1980). In 1991 only 12.6 percent of employed women were union members versus 19.3 percent of employed men (Crain, 1991). In 1992, Flaherty and Caniglia found that women are half as likely as men to be union members. 
What is ironic about these findings is that most previous estimates have shown that unionized women have a higher wage premium ${ }^{1}$ than their male counterparts (Oaxaca, 1975; Parsley, 1980), despite their low union representation. Furthermore, one study shows that three-fourths of the existing gender wage gap is explained by the low representation of women in highly organized occupations, reinforcing the magnitude of the union effect (Even and Macpherson, 1993). Given this evidence, increased union participation by women would provide a more equal distribution of earnings between men and women.

Thus, our aim is to update the union wage premium for different demographic groups to see if it has been affected by the recent decline in union membership, i.e., is there still a higher union wage premium for women as compared to men? Additional emphasis will be placed on the racial dimension within gender; for example, to see if nonwhite women gain more from membership than white women, as is the case with nonwhite men. Earlier research indicates that nonwhite women will not gain more than white women, given their tendency to work in uncovered, low-skill jobs (Ashraf, 1990). Our findings should have important implications for the recruiting strategies of unions and the future of female and nonwhite participation rates. Section II considers barriers to female and nonwhite union participation and recent trends in the unionization of various demographic groups.

\section{Barriers to Participation for Women and Nonwhites and Recent Trends in Union Membership}

There are three primary barriers to stronger female union participation: structural factors, social factors, and psychological factors. Structural factors include the fact that women are concentrated in the service sector, a highly nonunion area of the economy (Martin, 1985; Even and Macpherson, 1993). While females compose 90 percent of this sector, only 10 percent of service sector workers are union members (Baden, 1986). Because women tend to be affiliated with white-collar rather than with highly-unionized, blue-collar jobs (Cunnison and Stageman, 1993), they are further isolated from unions. Social factors focus on the dual role of women as workers in the labor force and as homemakers. With disproportionate family responsibilities, ${ }^{2}$ wives have less flexible schedules and hence less time to devote to union activities (Melcher et al., 1992; Trebilcock, 1990). Finally, psychological factors use gender differences to explain the lack of appeal that unions have for women. Psychologists argue that women view unions as a "male thing," involving characteristics that are inherently male (Cunnison and Stageman, 1993). Bargaining is aggressive and boasts a hostile environment that is unattractive to women (Cobble, 1990). There seems to be a "male culture" associated with unions, characterized by complicated procedures, sexist language, and jargon which is unappealing to women and further discourages their participation (Trebilcock, 1991).

In general, the values of men and women differ, so that the issues about which women feel most strongly do not coincide with the bread-and-butter issues with which 
unions are typically concerned. Where men seek more fringe benefits and higher pay, women still must contend with issues of equal pay and a desire for heightened community and service activities (Bergmann, 1986). Community concerns that include the preservation of public services and community institutions, as well as maternity leave, child care accommodations, and sexual harassment in the workplace, particularly for Asians and blacks who receive little respect compared to white women, are among the many issues neglected by unions (Baden, 1986; Cunnison and Stageman, 1993). Finally, a lack of female representation in union leadership positions creates the feeling that women have no influence in union settings and bargaining outcomes (Baden, 1986).

The barrier to nonwhite union participation can be attributed to one factor, discrimination. Ashenfelter's survey (1972) provides strong evidence that there is apparently less discrimination against black workers in the average unionized labor market than in the average nonunion labor market, but discrimination is not absent from the union sector. Furthermore, Gould (1977) claims that while unions purport to have a moral stance on discrimination, in practice, unions often constitute roadblocks to the achievement of nondiscriminatory employment. He identifies numerous issues on which black and union interests collide. Cook (1991) also argues that progress toward nondiscriminatory practices in unions has been slow, mainly due to the prolonged judicial process of outstanding affirmative action cases. In addition to these built-in barriers to unionization for women and nonwhites, there seems to be declining union participation rates across all demographic groups.

Declining union activity and membership in the 1980s, however, has been shown to have affected the union wage premiums of different demographic groups unevenly. Union membership for men decreased from 22.5 percent in 1984 to 12.5 percent in 1988, while women also suffered a decline, though smaller in magnitude, from 13.8 percent to 12.5 percent, respectively (Curme et al., 1990). Furthermore, disaggregation of union membership data ${ }^{3}$ shows a similar declining trend. From 1984 to 1995, unionization of white men fell 5.7 percentage points (from 22.3 pecent to 16.6 percent); white women's unionization fell 1.4 percentage points (from 12.7 percent to 11.3 percent); black men experienced the greatest decline, falling 7.7 percentage points (from 30.2 percent to 22.5 percent); and black women unionization fell 4.1 percentage points (from 21.7 percent to 17.6 percent). Similarly, Even and Macpherson (1993) show that between 1973 and 1988 private sector unionism declined 9.5 percentage points more for men than for women, a finding supported by Curme et al. (1990). Studies also show that union wage premiums have been generally rising since the 1970s (Lewis, 1986), but that females and nonwhites no longer gain the huge payoffs that previous research has suggested (Ashraf, 1990).

\section{Methodology, Data, and Empirical Results}

Our micro data are from the Panel Study of Income Dynamics (PSID) for the years 1980-1992. ${ }^{4}$ The following earnings model is estimated separately for male and female wage and salary workers for both races, i.e., white and nonwhites. The model controls 
for factors such as schooling, experience, tenure, the local unemployment rate, marital status, occupation, industry, and region.

$$
\begin{aligned}
& \operatorname{Ln} W=\alpha_{0}+\alpha_{1} E D U C 1+\alpha_{2} E D U C 2+\alpha_{3} E D U C 3+\alpha_{4} E D U C 4+\alpha_{5} E X P \\
& +\alpha_{6} E X P S Q+\alpha_{7} T E N U R E+\alpha_{8} \text { TENURESQ }+\alpha_{9} M A R R I E D \\
& +\alpha_{10} U R+\alpha_{11} O C C 1+\alpha_{12} O C C 2+\alpha_{13} O C C 3+\alpha_{14} O C C 4 \\
& +\alpha_{15} O C C 5+\alpha_{16} O C C 6+\alpha_{17} O C C 7+\alpha_{18} O C C 8+\alpha_{19} O C C 9 \\
& +\alpha_{20} O C C I 0+\alpha_{21} I N D I+\alpha_{22} I N D 2+\alpha_{23} I N D 3+\alpha_{24} I N D 4 \\
& +\alpha_{25} I N D 5+\alpha_{26} I N D 6+\alpha_{27} I N D 7+\alpha_{28} I N D 8+\alpha_{29} I N D 9 \\
& +\alpha_{30} I N D I 0+\alpha_{31} I N D I 1+\alpha_{32} N O R T H E+\alpha_{33} \text { WEST } \\
& +\alpha_{34} N O R T H C+\alpha_{35} A L A S K A+\beta_{1} U N I O N+\text { Error, }
\end{aligned}
$$

where LnW is the natural logarithm of workers' real hourly earnings in 1980 dollars. ${ }^{5}$

The above setup yields a total of $52(=4$ demographic groups $\times 13$ years) regressions. To get an estimate of overall, i.e., across all 4 demographic groups union wage premium, an additional 13 more regressions were run by combining the sample across all demographic groups. To allow for gender and race differences, GENDER and RACE dummies were added to the regressions based on the overall sample. Since the focus is on the union wage premium, only the estimated coefficient, i.e., $\hat{\beta}_{1}$, of the union dummy variable is reported in Table 1.6 From the reported summary of estimated union coefficient(s) several trends emerge. Specifically, the overall union wage premium during the sample years ranges between 22.3 and 28.4 percent. Nonwhite men (their premium ranges from 23.5 to 36.2 percent) have the most to gain, followed by white women (range 17.1 to 30.5 percent), white men (range 19 to 26.4 percent), and nonwhite women (range 10.2 to 20 percent ) ${ }^{7}$ In other words, nonwhite women have the least to gain. These trends are in accordance with earlier research (Lee, 1978; Lucas, 1977; Oaxaca, 1975). An illuminating way of looking at these trends is to examine the plot of the estimated union coefficients (Figure 1) - which indicates that even though nonwhite men and white women have the most to gain from unions, the racial wage gap for both genders is declining. This phenomenon is consistent with the "equalization hypothesis." That is, unions attempt to obtain equal absolute increases in wages for all union workers.

\section{Conclusion}

Union wage premiums converged across different demographic groups between 1980 and 1992. This trend could have important implications for the future of unions. If union membership can explain a portion of the gender/racial wage gap, and if women/nonwhites can obtain, through union membership, significant wage premia, increased female/nonwhite union participation in highly unionized sectors that offer high union wage gains could, in time, greatly decrease the gender/racial wage differential. Some possible changes in union tactics include a new focus on bargaining issues that address minorities' concerns, encouraging more spousal cooperation to alleviate the familial responsibilities that cause a conflict for wives, and increased representation of women and nonwhites in leadership positions to secure a strong female/nonwhite voice 


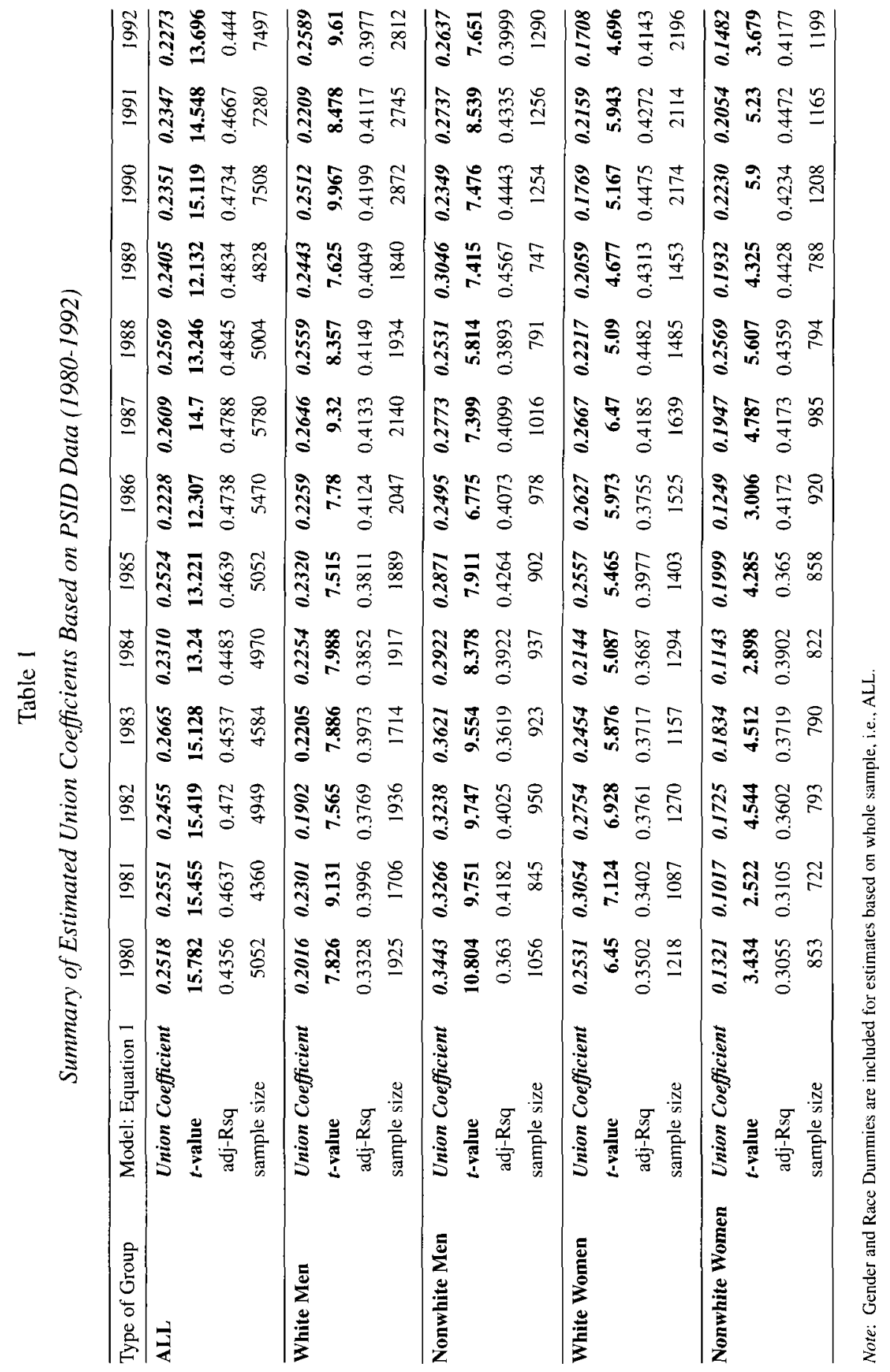


at collective bargaining tables. Given several years to restructure, unions have the potential to attract a large number of women/nonwhites, ultimately strengthening the trade union movement and improving the overall financial position of women/nonwhites in society.

Figure 1

\section{Plot of Estimated Union Coefficients based on PSID data (1980-92)}

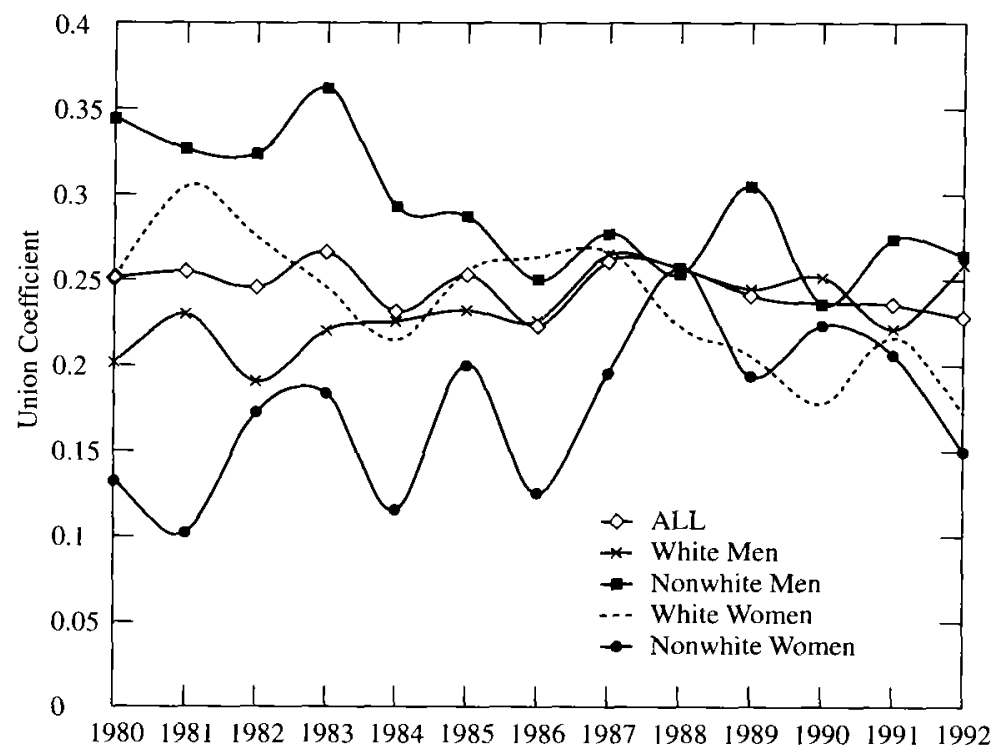

Note: Based on the estimated union coefficients reported in Table 1. 


\section{APPENDIX A \\ Variable Definitions}

Dependent Variable: $\operatorname{Ln} W=$ the natural logarithm of workers real hourly earnings in 1980 dollars

Education Dummies (omitting the category of non-high school graduates)

$E D U C 1=1$ if the worker graduated from high school; 0 otherwise.

$E D U C 2=1$ if the worker completed high school and non academic training, or attended college but did not receive a degree; 0 otherwise.

$E D U C 3=1$ if the worker received a $B A$ without attaining any advanced training; 0 otherwise.

$E D U C 4=1$ if the worker received a college degree plus advanced or professional training;

0 otherwise.

\section{Experience and Tenure Variables}

$E X P=$ the actual number years of experience the worker has in the job market.

$E X P S Q=$ the square of $E X P$.

$T E N U R E=$ the actual number of months the worker has been with his/her employer.

TENURESQ $=$ the square of TENURE.

\section{Unemployment and Marital Status Variables}

$U R=$ the local unemployment rate.

$M A R R I E D=1$ if the worker is married; 0 otherwise.

Occupation Dummies (omitting service workers and private household workers)

$O C C l$ : professional, technical

OCC2: managers and administrative

OCC 3: sales workers

OCC4: clerical workers

OCC5: craftsmen

OCC6: operatives

OCC7: transport equipment operatives

OCC8: laborers

OCC9: farmers and farm managers

OCC10: farm laborers and foremen

Industry Dummies (omitting the industry of public administration)

$I N D I$ : agriculture, forestry

IND2: mining and extraction

IND3: construction

IND4: manufacturing

IND5: transportation, communication

IND6: wholesale and retail trade

IND7: finance, insurance, real estate

IND8: business and repair services

IND9: personal services

IND 10: entertainment and recreational services

INDI1: professional services

Region Dummies (omitting the southern region)

NORTHE = the north-eastern region of the United States

NORTHC = the north-central region of the United States

$W E S T=$ the western region of the United States

$A L A S K A=$ Alaska and Hawaii

\section{Union Dummy}

UNION = 1 if the worker is a covered union nember; 0 otherwise 


\section{NOTES}

*This study was supported in part by National Science Foundation funds [OSR-9350540]. An earlier version of this paper was presented at the Southern Economic Association conference in New Orleans in 1995. We thank Emilia Lulcheva and Michael Lauze for their able research assistance and William Warren for his valuable editorial comments on an earlier draft of this paper. The usual caveat applies.

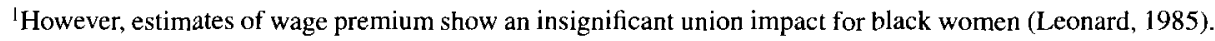

${ }^{2}$ Interestingly, Schur and Kruse (1992) found that family responsibilities are not barriers to unionization.

${ }^{3}$ Statistical Abstract of the United States (various years), and Employment and Earnings (January issue, various years).

${ }^{4}$ The data are compiled by the Inter-university Consortium for Political and Social Research Center at the University of Michigan.

${ }^{5}$ All of the independent variables used in equation (1) are presented in Appendix A.

${ }^{6}$ Full regression results can be obtained by request. All the included human capital and demographic variables are both statistically significant and have the right signs.

${ }^{7}$ This wage premium value of 20 percent more accurately represents the upper bound for nonwhite women. However, in 1988 the results indicate that the union wage premium for nonwhite women was 25.7 percent.

\section{REFERENCES}

Abowd, John M. and Henry S. Farber. "Job Queues and the Union Status of Workers." Industrial and Labor Relations Review 35 (April 1982): 354-67.

Ashenfelter, Orley. "Racial Discrimination and Trade Unionism." Journal of Political Economy 80 (May-June 1972): 435-64.

Ashraf, Javed. "Recent Trends in the Union Wage Premium." Journal of Labor Research 1 ( (Fall 1990): 435-51.

Baden, Naomi. "Developing an Agenda: Expanding the Role of Women in Unions." Labor Studies Journal 10 (Winter 1986): 229-49.

Bergmann, Barbara R. The Economic Emergence of Women. New York: Basic Books, 1986.

Cobble, Dorothy Sue. "Rethinking Troubled Relations between Women and Unions: Craft Unionism and Female Activism." Feminist Studies 16 (Fall 1990): 519-48.

Cook, Alice H. "Women and Minorities." The State of the Unions. George Strauss, Daniel G. Gallagher, and Jack Fiorito, ed. Madison, Wisc.: Industrial Relations Research Association, 1991.

Crain, Marion. "Gender and Union Organizing." Industrial and Labor Relations Review 17 (January 1991): $227-48$.

Cunnison, Sheila and Jane Stageman. Feminizing the Unions. London: Avebury, 1993.

Curme, Michael A., Barry T. Hirsch, and David A. Macpherson. "Union Membership and Contract Coverage in the United States, 1983-1988." Industrial and Labor Relations Review 44 (October 1990): 5-35.

Even, William E. and David A. Macpherson. "Decline of Private Sector Unionism and the Gender Wage Gap." Journal of Human Resources 28 (Spring 1993): 279-96.

Farber, Henry S. "Trends in Worker Demand for Union Representation." American Economic Review 79 (May 1989): 166-71. 

1417-37.

"The Determination of the Union Status of Workers." Econometrica 51 (September 1983):

Flaherty, Sean and Alan Caniglia. "The Relative Effects of Unionism on the Earnings Distribution of Women and Men." Industrial Relations 31 (Spring 1992): 382-93.

Gould, William. Black Workers in White Unions: Job Discrimination in the United States. Ithaca, N.Y.: Cornell University Press, 1977.

Hills, Stephen. "The Attitudes of Union and Nonunion Male Workers toward Union Representation." Industrial and Labor Relations Review 38 (January 1985): 179-94.

Hirsch, Barry T. and John T. Addison. The Economic Analysis of Unions. Boston, Mass.: Allen and Unwin, 1986.

Lee, Lung-Fei. "Unionism and Wage Rates: A Simultaneous Equations Model with Qualitative and Limited Dependent Variables." International Economic Review 19 (June 1978): 415-33.

Leonard, Jonathan S. "The Effect of Unions on the Employment of Blacks, Hispanics and Women." Industrial and Labor Relations Review 39 (October 1985): 115-32.

Lewis, H. Gregg. Union Relative Wage Effects. Chicago: University of Chicago Press, 1986.

Lucas, Robert. "Hedonic Wage Equations and Psychic Wags in the Return to Schooling." American Economic Review 67 (September 1977): 549-58.

Martin, George T., Jr. “Union Social Services and Women's Work.” Social Science Review 59 (March 1985): $62-74$.

Melcher, Dale, Jennifer L. Eihstedt, Shelley Erikson, and Dan Clawson. "Women's Participation in Local Union Leadership: The Massachusetts Experience." Industrial and Labor Relations Review 45 (January 1992): 267-80.

Oaxaca, Ronald L. "Estimation of Union/Nonunion Wage Differentials within Occupational/Regional Subgroups." Journal of Human Resources 10 (Fall 1975): 529-37.

Parsley, Christopher J. "Labor Union Effects on Wage Gains: A Survey of Recent Literature." Journal of Economic Literature 18 (March 1980): 1-31.

Schur, Lisa A. and Douglas L. Kruse. "Gender Differences in Attitudes toward Unions." Industrial and Labor Relations Review 46 (October 1992): 89-102.

Trebilcock, Anne. "Strategies for Strengthening Women's Participation in Trade Union Leadership." International Labor Review 130 (April 1991): 407-26. 